JCE (Journal of Childhood Education)

Vol. 4 No. 2 Tahun 2020 | Hal. 93 - 102

2620-3278 (E-ISSN), 2598-2184 (P-ISSN)

\title{
PENINGKATAN KEMAMPUAN MENYIMAK ANAK USIA DINI DENGAN MEDIA BONEKA TONGKAT
}

\section{Ayunda Sayyidatul Ifadah ${ }^{1}$}

Universitas Muhammadiyah Gresik, Indonesia

yundasi@umg.ac.id

\begin{tabular}{l}
\hline Informasi artikel \\
\hline Received : \\
August 13, 2020. \\
Revised : \\
August 26, 2020. \\
Publish : \\
September 09, 2020.
\end{tabular}

Kata kunci:

Media boneka

tongkat;

Kemampuan

menyimak;

Anak usia dini;

Keywords:

Puppet stick media;

Listening ability;

Early childhood;

\begin{abstract}
ABSTRAK
Penelitian ini bertujuan mengetahui pengaruh penggunaan media boneka tongkat terhadap kemampuan menyimak anak kelompok A TK N Pembina Kabupaten Gresik. Penelitian ini menggunakan metode penelitian Quasi Eksperimen dengan dengan tipe Nonequivalent Control Group Design. Populasi penelitian ini seluruh anak TK N Pembina Kabupaten Gresik, dengan sampel kelas A1 sebagai kelas eksperimen dan A2 sebagai kelas kontrol. Teknik pengumpulan data yang digunakan adalah observasi. Hasil penelitian menunjukkan bahwa pengaruh penggunaan media boneka tongkat terhadap kemampuan menyimak anak kelompok A TK N Pembina Kabupaten Gresik, hal ini dibuktikan dari hasil perhitungan uji t diperoleh nilai p 0,00 lebih kecil dari 0,05.

\section{ABSTRACT}

This study aims to determine the effect of the use of puppet media on the ability to listen to children in group A TK N Pembina District Gresik. This study used the Quasi Experiment research method with the Nonequivalent Control Group Design type. The population of this study were all TK N Pembina District children in Gresik, with samples class Al as the experimental class and $A 2$ as the control class. The data collection technique used is observation. The results showed that the effect of the use of puppet media on the ability to listen to children in group A TK N Pembina District of Gresik, this was evidenced from the results of t test calculations obtained p value 0.00 less than 0.05 .
\end{abstract}




\section{PENDAHULUAN}

Pendidikan Anak Usia Dini (PAUD) adalah pemberian upaya untuk menstimulasi, membimbing, mengasuh, dan pemberian kegiatan pembelajaran yang menghasilkan kemampuan dan keterampilan anak (Sujiono, 2011). PAUD adalah awal peletakan dasar sebelum anak memulai jenjang pendidikan selanjutnya (Permendikbud, 2014). Sebagai peletak dasar perkembangan PAUD memiliki dua bidang pengembangan, yaitu bidang pengembangan pembiasaan dan bidang kemampuan dasar. Perilaku anak yang meliputi keagamaan, sosial, emosional, dan kemandirian dikembangkan pada bidang pengembangan pembiasaan,. Dan kemampuan anak yang meliputi kemampuan berbahasa, kognitif, fisik/motorik, dan seni dikembangkan pada pengembangan kemampuan dasar (Aqib, 2009). Kemampuan yang dikembangkan pada bidang pengembangan tersebut mempunyai andil besar dalam kehidupan anak tak terkecuali kemampuan berbahasa.

Kemampuan berbahasa ini penting peranannya dalam kehidupan, Beitchman \& Brownlie menyatakan bahwa "language is central to social life; speech and language development is a cornerstone for successful outcomes later in life". Laird (Dhieni, 2008) memperkuat dengan menyatakan "tiada kemanusiaan tanpa bahasa dan tidak ada peradaban tanpa bahasa lisan". Sangat jelas bahwa berbahasa memiliki andil besar dalam kehidupan, jika kita ingin berhasil di masyarakat dan menjadi orang yang sukses maka kita harus mempunyai kemampuan berbahasa yang baik. Masa atau periode penting (critical - period) dalam mempelajari Bahasa adalah pada tahun awal masa kanak - kanak (Susanto, 2012). Broomley (Dhieni, 2008) menyebutkan bahwa ada 4 macam kemampuan berbahasa yaitu menyimak, berbicara, membaca dan menulis. Keempat kemampuan berbahasa tersebut saling mempengaruhi satu sama lain. Menyimak adalah kemampuan awal yang dipelajari diantara ketiga kemampuan http://journalfai.unisla.ac.id/index.php/JCE 
lainnya. Karena sebelum anak mampu berbicara, membaca, dan menulis, anak terlebih dahulu menyimak yang ada disekitarnya. Hal ini dinyatakan oleh Tarigan (2015) "pada masa kecil kita belajar menyimak bahasa kemudian berbicara, sesudah itu kita membaca dan menulis".

Kegiatan pengembangan kemampuan menyimak dalam realitanya, kegiatan yang diberikan adalah tugas mengerjakan Lembar Kerja Anak (LKA), sehingga anak hanya berkutat pada kertas, krayon, dan spidol. sehingga pemenuhan kebutuhan anak kurang maksimal. Hal ini berdasarkan observasi dan wawancara di salah satu TK Pembina di Gresik, 30\% anak kelompok A di TK Pembina Gresik kemampuan menyimak anak masih dalam tahap kurang berkembang. Dalam perkembangan bahasa khususnya menyimak, lebih terlihat pada saat apersepsi tema daripada kegiatan inti. Padahal kegiatan inti dengan menggunakan media yang menarik dapat menggugah minat anak terhadap materi yang akan disampaikan. Anak akan lebih memperhatikan isi cerita yang disampaikan oleh guru. Karena melalui media anak mendapatkan pengalaman yang konkret (Eliyawati, 2005), sehingga pesan yang disampaikan benar - benar dapat mencapai sasaran dan tujuan yang ingin dicapai. Media sendiri adalah salah satu prinsip pembelajaran anak usia dini (Permendikbud, 2014).

Media dalam kegiatan pembelajaran memiliki kontribusi yang sangat penting, diantaranya yaitu : penyampaian pesan pembelajaran dapat lebih terstandar, pembelajaran dapat lebih menarik, pembelajaran menjadi lebih interaktif, waktu pembelajaran dapat diperpendek, kualitas pembelajaran dapat ditingkatkan, proses pembelajran dapat berlangsung kapan pun dan di mana pun diperlukan, sikap positif siswa terhadap materi pembelajaran serta proses pembelajaran dapat ditingkatkan, dan peran guru berubah ke arah yang positif, artinya guru tidak menempatkan diri sebagai 
satu - satunya sumber belajar (Sudjana \& Rivai, 2013). Salah satu media yang bisa digunakan adalah boneka tongkat, karena media boneka tongkat sangat menarik baik dari segi bentuk, maupun penggunaannya. Ahlcrona menyatakan (Brits, J. S., Potgieter, A., \& Potgieter, 2014) "a puppet is a movable object or figure that can be controlled by strings, rods or by placing one's hand inside its body. They are perfect for grabbing the attention of children". Ahlcrona menjelaskan bahwa tangan boneka tongkat yang mudah digerakkan dapat memberikan daya tarik tersendiri saat digunakan. Selain itu media boneka tongkat merupakan media visual yang dalam kerucut pengalaman Dale memiliki presentasi kekonkretkannya adalah 50\% (Munadi, 2013) Berdasarkan latar belakang diatas menggugah peneliti untuk menggunakan media boneka tongkat untuk mengembangkan kemampuan menyimak anak. Penggunaan media boneka tongkat dapat menarik perhatian anak dan memberikan kesan khusus terhadap anak.

\section{METODE}

\section{Jenis Penelitian}

Penelitian ini menggunakan metode Quasi Eksperimen dengan tipe Nonequivalent Control Group Design.

\section{Waktu dan Tempat Penelitian}

Penelitian ini dilaksanakan pada anak kelompok A TK N Pembina Kabupaten Gresik, yang beralamay di Jl. Balikpapan 2 GKB, Manyar, Yosowilangun, Kec. Manyar, Kab. Gresik Prov. Jawa Timur. Penelitian ini dimulai pada bulan bulan April - Mei 2016.

\section{Populasi dan Sampel Penelitan}

Populasi dalam penelitian ini adalah seluruh peserta didik di TK N Pembina Kabupaten Gresik yang terdiri dari empat kelas (A1, A2, B1, dan B2) yang berjumlah 122. 


\section{Sampel}

Pengambilan sampel penelitian ini dengan teknik purposive sampling. Teknik ini bertujuan untuk menentukan sampel dengan pertimbangan tertentu (Sugiono, 2015). Pada penentuan sampel ini yang menjadi pertimbangan adalah usia dan perkembangan anak. Sehingga kelas yang memenuhi kriteria tersebut adalah kelas A1 dan A2.

\section{Prosedur}

Pada jenis penelitian Quasi Eksperimen dengan tipe Nonequivalent Control Group Design, dapat digambarkan dalam tabel berikut.

Tabel 1. Desain Penelitian

\begin{tabular}{cccc}
\hline Kelompok & $\begin{array}{c}\text { Pre- } \\
\text { test }\end{array}$ & Perlakuan & $\begin{array}{c}\text { Post- } \\
\text { test }\end{array}$ \\
Eksperimen & $\mathrm{O}_{1}$ & $\mathrm{X}$ & $\mathrm{O}_{2}$ \\
Kontrol & $\mathrm{O}_{3}$ & - & $\mathrm{O}_{4}$ \\
\hline
\end{tabular}

(Sugiono, 2015)

Keterangan :

$\mathrm{O}_{1} \quad=$ nilai sebelum diberi perlakuan pada kelas eksperimen

$\mathrm{O}_{2}=$ nilai kelas eksperimen setelah diperlakuan

$\mathrm{X}=$ penggunaan media boneka tongkat yang dikembangkan pada kelas eksperimen

$\mathrm{O}_{3}=$ nilai sebelum diberi perlakuan pada kelas kontrol

$\mathrm{O}_{4} \quad=$ nilai sesudah diberi perlakuan pada kelas kontrol

- $\quad=$ kelas kontrol tidak diberi perlakuan 


\section{Teknik Pengumpulan Data}

Teknik pengumpulan data dilakukan dengan melihat perbedaan hasil observasi dari nilai sebelum dan sesudah perlakuan $\mathrm{O}_{1}$ dan $\mathrm{O}_{2}$ pada kelas eksperimen dengan $\mathrm{O}_{3}$ dan $\mathrm{O}_{4}$ pada kelas kontrol. Sehingga dapat diketahui perbedaan antara $\mathrm{O}_{1}$ dan $\mathrm{O}_{2}$ pada kelas eksperimen dengan $\mathrm{O}_{3}$ dan $\mathrm{O}_{4}$ pada kelas kontrol.

\section{Teknik Analisis Data}

Analisis data dalam penelitian ini menggunakan SPSS 23.00 for windows, tahapannya adalah sebagai berikut :

1) Uji Normalitas data yaitu teknik pengujian data yang dilakukan untuk mengetahui sebaran data memenuhi asumsi normal, uji normalitas diukur dengan kriteria :

a. Jika nilai signifikasi atau probabilitas $>0,05$ maka data berdistribusi normal.

b. Jika nilai signifikasi atau probabilitas $<0,05$ maka data berdistribusi tidak normal.

2) Uji homogenitas dimaksudkan untuk mengetahui homogenitas varians data pada kedua kelas perlakuan. Pengujian homogenitas menggunakan uji Levene dengan bantuan program SPSS. Adapun kriteria pengujian :

a. Jika nilai signifikasi hasil perhitungan $(\mathrm{p})>0,05$ maka data dinyatakan homogen.

b. Jika nilai signifikasi hasil perhitungan $(\mathrm{p})<0,05$ maka data dinyatakan tidak homogen.

Apabila data berdistribusi normal dan homogen maka alat analisis yang digunakan adalah uji independent $t$ test. Dan apabila data tidak berdistribusi normal dan homogen maka alat analisis yang digunakan adalah uji beda wilcoxon (Mann Whitney U Test). 


\section{PEMBAHASAN}

Pada pretest anak kelompok A1 dan A2 melakukan kegiatan bercerita tanpa menggunakan media apapun. Kemudian pada posttest anak kelompok A1 melakukan kegiatan bercerita melakukan kegiatan bercerita tanpa menggunakan media, dan anak kelompok A2 menggunakan media boneka tongkat. Sebelum melakukan pengujian Independen $t$-test, peneliti perlu mengetahui normalitas dan homogenitas data. Jika normalitas dan homogenitas data terpenuhi maka t-test bisa digunakan, tetapi jika normalitas dan homogenitas data tidak terpenuhi maka akan digunakan uji Wilcoxon(Mann Whitney U Test) (MacMillan, 1.c., Chen, 1992). Berikut ini adalah hasil dari uji normalitas pada data hasil pretest dan posttest:

Berdasarkan uji Kolmogorov-Smirnov a dan Shapiro-Wilk, signifikansi yang diperoleh adalah 0,000 dan 0,000. Kedua nilai tersebut berada di bawah level signifikansi yang digunakan untuk menentukan normalitas data dalam penelitian ini yaitu 0,05. Dengan demikian, data hasil kemampuan menyimak tidak terdistribusi dengan normal. Berdasarkan uji Test of Homogeneity of Variances, signifikansi yang diperoleh adalah 0,976 . Nilai tersebut berada di atas level signifikansi yang digunakan untuk menentukan homogenitas data dalam penelitian ini yaitu 0,05 . Dengan demikian, data hasil kemampuan menyimak kelas kontrol dan kelas eksperimen sebelum pembelajaran adalah adalah homogen. Dengan melihat hasil diatas, dapat diketahui bahwa dari uji normalitas yang telah dilakukan semua data tidak berdistribusi normal. Sedangkan pada uji homogenitas, semua data homogen atau bisa dikatakan kedua kelompok kelas data yang digunakan memiliki varians yang relatif 
sama. Karena tidak berdistribusi normal namun homogen, maka t-test masih relevan dilakukan.

Data hasil uji Independen $t$ - test untuk mengetahui kemampuan menyimak pada kelas kontrol (tanpa menggunakan media boneka tongkat) dan kelas eksperimen (menggunakan media boneka tongkat) menunjukkan nilai Sig (2 tailed) atau p value. Nilai $\mathrm{p}$ value sebesar 0,000 di mana $<0,05$. Karena $<0,05$, maka terdapat pengaruh bermakna antara dua kelompok kelas atau yang berarti Ha diterima. Dapat disimpulkan bahwa media boneka tongkat berpengaruh terhadap kemampuan menyimak anak kelompok A2 TK N Pembina Kabupaten Gresik. Peningkatan kemampuan menyimak anak setelah diberikan perlakuan merupakan bentuk keberhasilan dalam penggunaan media boneka tongkat, sehingga perhatian anak terhadap materi yang akan disampaikan meningkat. Isi cerita yang disampaikan oleh guru dengan menggunakan media boneka tongkat lebih tersampaikan kepada anak. Hasil penelitian di TK N Pembina Kabupaten Gresik senada dengan hasil penelitian dari Muhana Gipayana (2013), hasil penelitian yang diperoleh adanya perbedaan signifikan antara yang mengikuti pembelajaran menggunakan media boneka tangan dengan yang mengikuti tanpa menggunakan media boneka tangan. Vida Zuljevic (Isbell, Rebecca, Sobol, Joseph, Lindauer, Liane, 2004) yang menemukan bahwa penggunaan media boneka dalam kegiatan pembelajaran dapat meningkatkan keterlibatan anak, motivasi, dan pengembangan anak membaca, bahasa lisan, dan kemampuan berkomunikasi. Brits juga menyebutkan dalam penelitiannya bahwa media boneka mampu merangsang imajinasi, mendorong bermain kreatif, dan menemukan sendiri sebuah pengetahuan. Peningkatan kemampuan menyimak anak juga dikarenakan penggunaan media boneka tongkat yang menarik dapat menggugah minat anak terhadap materi yang akan 
disampaikan. Anak akan lebih memperhatikan isi cerita yang disampaikan oleh guru. Sehingga pesan yang ingin disampaikan kepada anak akan tersampaikan dengan baik. Media boneka tongkat ini menarik dari segi bentuk, dan penggunaannya. Tangan boneka yang mudah digerakkan dapat memberikan daya tarik tersendiri saat digunakan. Penggunaan media dalam penelitian ini seperti apa yang dinyatakan oleh Ahlcrona (dalam Brits, Potgieter, \& Potgieter, 2014) "a puppet is a movable object or figure that can be controlled by strings, rods or by placing one's hand inside its body. They are perfect for grabbing the attention of children”. Selain itu wajah boneka tongkat yang dapat berubah sesuai dengan adegan yang sedang terjadi juga merupakan daya tarik tersendiri untuk anak.

\section{KESIMPULAN}

Penggunaan Media boneka tongkat terbukti efektif meningkatkan kemampuan menyimak anak usia dini. Data hasil uji Independen $t$ - test untuk mengetahui kemampuan menyimak pada kelas kontrol (tanpa menggunakan media boneka tongkat) dan kelas eksperimen (menggunakan media boneka tongkat) menunjukkan nilai Sig (2 tailed) atau p value. Nilai p value sebesar 0,000 di mana < 0,05 . Karena $<0,05$, maka terdapat pengaruh bermakna antara dua kelompok kelas atau yang berarti Ha diterima. Dengan demikian, dapat disimpulkan bahwa media boneka tongkat berpengaruh untuk meningkatkan kemampuan menyimak anak kelompok A2 TK N Pembina Kabupaten Gresik. 


\section{REFERENSI}

Aqib, Z. (2009). Belajar Dan Pembelajaran Di Taman Kanak-Kanak. Yrama Widya. Brits, J. S., Potgieter, A., \& Potgieter, M. J. (2014). Exploring The Use Of Puppet Shows In Presenting Nanotechnology Lessons In Early Childhood Education. International Jurnal For Cross-Disciplinary Subjects In Education (IJCDSE), $5(4), 1798-1803$.

Dhieni, N. (2005). Metode Pengembangan Bahasa. J. In Metode pengembangan bahasa. Universitas Terbuka.

Eliyawati, C. (2005). Pemilihan dan pengembangan sumber belajar untuk anak usia dini. In Jakarta: Depdiknas. Depdiknas.

Isbell, Rebecca, Sobol, Joseph, Lindauer, Liane, \& L. (2004). The Effects Of Storytelling And Story Reading On The Oral Language Complexity And Story Comprehension Of Young Children. Early Chilhood Education Journal, 32(3), 157-163.

Kebudayaan, P. M. P. D., \& Indonesia, R. (2014a). Kurikulum 2013 Pendidikan Anak Usia Dini No.146 Tahun 2014. Permendikbud.

Kebudayaan, P. M. P. D., \& Indonesia, R. (2014b). Standar Nasional Pendidikan Anak Usia Dini. Peraturan Menteri Pendidikan Dan Kebudayaan Republik Indonesia.

MacMillan, 1.c., Chen, \& M.-J. . (1992). Nonresponse and Delayed Response to Competitive Moves The Roles of Competitor Dependence and Action Irreversibility. Academy of Management Journal, 35, 359-370.

Muhana Gipayana, R. (2013). Pengaruh Media Boneka Tangan Terhadap Kemampuan Menyimak Isi Dongeng Mata Pelajaran Bahasa Jawa Siswa Sekolah Dasar. Sekolah Dasar, 1(1), 48-55. http://journal.um.ac.id/index.php/jurnal-sekolahdasar/article/view/4229

Munadi, Y. (2013). Media Pembelajaran sebuah Pendekatan Baru. GP Press Group.

Sudjana, N., \& Rivai, A. (2013). Media Pengajaran. Sinar Baru Algesindo.

Sugiono. (2015). Memahami Penelitian Kualitatif. Alfabeta.

Sujiono, Y. N. (2011). Konsep Dasar Pendidikan Anak Usia Dini. Indeks.

Susanto, A. (2012). Perkembangan Anak Usia Dini Pengantar Dalam Berbagai Aspeknya. Prenada Media Group.

Tarigan, H. G. (2015). Menyimak Sebagai Suatu Keterampilan Berbahasa. Angkasa Bandung. 